\title{
FORMULASI DAN UJI STABILITAS SEDIAAN LULUR DARI RIMPANG KUNYIT (CURCUMA LONGA LINN)
}

\author{
Rani Prabandani ${ }^{1)}$ Hilda Suherman ${ }^{2)}$ \\ 1),2) Program Studi Farmasi Sekolah Tinggi Ilmu Kesehatan Harapan Bangsa Purwokerto \\ ${ }^{1)}$ Raniprabandari@shb.ac.id , ${ }^{2)}$ hildasuherman@shb.ac.id
}

\begin{abstract}
ABSTRAK
Lulur adalah jenis kosmetik yang dibuat dari bunga-bunga dan bahan-bahan tanaman lainya yang sangat bermanfaat untuk menjaga kecantikan, kesehatan, kehalusan dan kecerahan kulit tubuh. Lulur dapat membantu membersihkan kotoran yang menempel dikulit akibat pengaruh faktor cuaca dan polusisehingga kulit menjadi sehat, bersih dan cantik. Kandungan zat senyawakunyit antara lain:kurkuminoid yangterdiri dari kurkumin, desmetoksikumin dan bisdesmetoksikurkumin serta zat-zat manfaat lainnya, seperti minyak asiri volatil oil, lemak, karbohidrat, protein, pati, vitamin $\mathrm{C}$, zat besi, fosfor, dan kalsium. Curcumin adalah zat warna kuning yang dikandung oleh kunyit, rata-rata 10,29\%, memiliki aktifitas biologis berspektrum luas antara lain antihepototoksik, antibakteri dan antioksidan sehingga kunyit mampu digunakan untuk obat tradisional baik menjaga esehatan maupun kecantikan kulit tubuh, Metode yang digunakan adalah studi eksperimental sediaan lulur serta dilakukan pengujian stabilitas lulur yang mengandung serbuk rimpang kunyit. Sediaan lulur yang terbaik adalah formula 1 yang menggunakan perbandingan serbuk rimpang kunyit memiliki lulur warna coklat muda, lulur homogen dan menyatu sempurna, memiliki pH 5, daya sebar 10,321 $\mathrm{cm} 2$, memiliki konsistensi viskositas $99.000 \mathrm{mPa} . \mathrm{s}$ dan daya lekat selama 4 detik.
\end{abstract}

Kata kunci : formulasi, lulur, kunyit.

\section{ABSTRACT}

Lulur is a type of cosmetics made from flowers and other plant ingredients that are very useful for maintaining beauty, health, smoothness and brightness of the skin of the body. Lulur can help clean the dirt that sticks to the skin due to the influence of weather and pollution factors so that the skin becomes healthy, clean and beautiful. The contents of the substance include turmeric: curcuminoid which consists of curcumin, desmetoksikumin and bisdesmetoksikurkumin and other beneficial substances, such as volatile essential oils of oil, fat, carbohydrates, protein, starch, vitamin C, iron, phosphorus, and calcium. Curcumin is a yellow substance contained by turmeric, on average 10.29\%, has broad spectrum biological activity including antihepototoxic, antibacterial and antioxidant so that turmeric is able to be used for traditional medicine both to maintain health and skin beauty of the body, The method used is study experimental scrubs and tested the stability of scrubs containing turmeric rhizome powder. The best scrubs are formula 1 which uses the ratio of turmeric powder to light brown scrub, homogeneous and perfectly fused body scrub, has a pH of 5 , spread of 10,321 cm2, has a viscosity consistency of 99,000 mPa.s and adhesion for 4 seconds.

Keywords: formulations, scrubs, turmeric. 


\section{PENDAHULUAN}

Kesehatan merupakan salah satu kebutuhan dasar manusia, itulah sebabnya upaya untuk mencapai tingkat kesehatan yang optimal sangat diperlukan. Berbagai upaya dilakukan masyarakat untuk hidup dengan sehat bersama keluarga. Sebelum zaman berkembang pada umumnya masyarakat melakukan pengobatan tradisional yang bahan dasar obatnya berasal dari tumbuhan- tumbuhan yang mereka kenal dan berfungsi sebagai obat (Prakash, 2001).

Dalam perawatan, mengenal jenis kulit merupakan hal utama yang harus dilakukan supaya tidak terjadi kesalahan dalam memilih kosmetika serta menentukan teknik perawatannya. Jenis kulit tersebut dapat dibedakan atas beberapa jenis yakni: (1) jenis kulit kering (2) jenis kulit berminyak (3) jenis kulit kombinasi dan (4) jenis kulit normal, Nur'an (2009:43-45).

Jenis kulit kering sering cendrung lebih bermasalah dibanding jenis kulit lainnya. Kulit kering disebabkan karena tidak cukupnya minyak yang dihasilkan oleh kelenjer minyak, sehingga membuat kulit tidak lembab dan menjadi kering. Hal ini dapat menimbulkan masalah pada kulit seperti: kulit terlihat kasar, berkeriput dan kusam.
Kunyit dengan bahasa saintifiknya bernama Curcuma domestica Val. Depkes RI, (2002) menyatakan selain tanaman kunyit sebagai bumbu dapur, kunyit juga digunakan untuk kecantikan kulit, melindungi kulit tubuh akibat sinar matahari. Kandungan zat senyawakunyit antara lain:kurkuminoid yangterdiri dari kurkumin, desmetoksikumin dan bisdesmetoksikurkumin serta zat-zat manfaat lainnya, seperti minyak asiri volatil oil, lemak, karbohidrat, protein, pati, vitamin $\mathrm{C}$, zat besi, fosfor, dan kalsium. Curcumin adalah zat warna kuning yang dikandung oleh kunyit, rata-rata 10,29\%, memiliki aktifitas biologis berspektrum luas antara lain antihepototoksik, antibakteri dan antioksidan sehingga kunyit mampu digunakan untuk obat tradisional baik menjaga esehatan maupun kecantikan kulit tubuh, (DokterGaul.com-27/08/2012/net).

Dalam hal ini, dikarenakan seringnya mengabaikan kesehatan dan kurangnya melakukan perawatan kulit tubuh. Misalnya, pada saat mereka keluar rumah/berpergian, mereka tidak menggunakan payung, tidak menggunakan pelindung (sunblock), juga faktor cuaca, polusi, debu dan paparan sinar matahari yang terus membakar kulit, sehingga terdapatnya sel-sel kulit mati, sel-sel kulit 
mati inilah yang dapat menyebabkan pigmentasi kusam pada kulit tubuh. Kulit kusam jelas akan mengurangi keindahan kulit, kulit terlihat kasar dan kusam,hal ini mengurangi daya tarik penampilan seseorang dalam bergaul.

\section{METODE PENELITIAN}

\section{Alat dan Bahan}

Alat - alat yang digunakan dalam penelitian yaitu pisau, tampah, alat tumbuk kopi tradisional, timbangan digital, cawan porselin, batang pengaduk, mortar, stamper, sudip, beker gelas, gelas ukur, water bath, pot/ tempat kosmetik, alat daya lekat, objek gelas, $\mathrm{pH}$ meter, viskometer boorkfield, estensometer. Bahan - bahan yang digunakan yaitu serbuk rimpang kunyit, tepung beras, aquadest, madu, cetyl alcohol, propilen glikol, tritanolamin, asam stearate, liserin, nipagin.

\section{Determinasi Tanaman}

Determinasi rimpang kunyit (Curcuma domesticae rhizoma) dilakukan dengan mencocokan dari morfologi yang ada pada rimpang kunyit (Curcuma domesticae rhizoma) terhadap pustaka dan dibuktikan di Laboratorium Biologi Universitas Harapan Bangsa Purwokerto.

\section{Pengambilan Sampel}

Sampel rimpang kunyit (Curcuma domesticae rhizoma) diperoleh di desa Ledug Kec. Kembaran Kabupaten Banyumas Provinsi Jawa Tengah. Pengambilan sampel dilakukan pada pagi hari dengan cara mengambil atau mencabut tanaman kunyit (Curcuma domesticae. Val) lalu memilih rimpang kunyit (Curcuma domesticae rhizhoma) yang tidak rusak untuk dijadikan sampel.

\section{Pengolahan sampel}

Sampel rimpang kunyit (Curcuma domesticae rhizoma) yang telah diambil dicuci bersih dengan air mengalir lalu ditiriskan. Rimpang kunyit yang sudah bersih disortasi basah dan ditimbang. Selanjutnya rimpang diiris tipis dengan ketebalan berkisar 1-3 $\mathrm{mm}$, lalu dikeringkan selama 4 hari dalam Oven dengan suhu $\pm 40^{\circ} \mathrm{C}$. Simplisia yang telah kering diblender menjadi serbuk kasar lalu disimpan di dalam wadah plastik bertutup

\section{Pembuatan Lulur}

Fase minyak (cetyl alcohol dan asam stearate) dan fase air (propilen glikol, gliserin, trietanolamin dan air) di leburkan di atas water bath pada suhu $70^{\circ} \mathrm{C}$. fase air dan fase minyak dimasukan 
ke dalam mortar panas aduk hingga beras lalu aduk ad homogen. Dibiarkan membentuk basis body scrub, kemudian dingin lalu pindah pada pot. tambahkan serbuk kunyit dan tepung

\begin{tabular}{cccc}
\hline Bahan & Formula 1 & Formula 2 & Formula 3 \\
\hline Kunyit & 10 & 5 & 10 \\
\hline Tepung beras & 5 & 10 & 10 \\
\hline Cetyl alcohol & 3 & 3 & 3 \\
\hline Asam stearate & 5 & 5 & 5 \\
\hline Propilen glikol & 5 & 5 & 5 \\
\hline Gliserin & 15 & 15 & 15 \\
\hline Trietanolamin & 4 & 4 & 4 \\
\hline Air & 53 & 53 & 48
\end{tabular}

Keterangan : komposisi bahan dalam persen (\%)

\section{Uji Sifat Fisik Lulur}

Uji sifat fisik lulur antara lain uji organoleptis, uji homogenitas, uji $\mathrm{pH}$, uji viskositas, uji daya sebar, uji daya lekat.
Uji organoleptis digunakan untuk memeriksa tampilan fisik dari sediaan lulur menggunakan panca indra. Pemeriksaan meliputi tekstur, bentuk, warna, bau dari sediaan.

\section{HASIL DAN PEMBAHASAN}

A. Hasil Uji Organoleptis

Tabel 1. Hasil uji organoleptis

\begin{tabular}{llll}
\hline Formula & Bentuk & Warna & Bau \\
\hline F1 & Lulur & Coklat muda & Khas kunyit \\
\hline F2 & Lulur & Coklat tua & Khas kunyit \\
\hline F3 & Lulur & Coklat tua & Khas kunyit \\
\hline Lulur X & Lulur & Putih Tulang & Khas strawberry \\
\hline
\end{tabular}

Tabel 2. Hasil Uji Sifat Fisik 


\begin{tabular}{llll}
\hline Formula & Homogenitas & PH & Viskositas mPa.s \\
\hline F1 & Homogen & 5 & 99.000 \\
\hline F2 & Homogen & 5 & 100.000 \\
\hline F3 & Homogen & 5 & 100.000 \\
\hline Lulur X & Homogen & 6 & 51.000 \\
\hline
\end{tabular}

\section{B. Uji Homogenitas}

Berdasarkan hasil uji homogenitas (tabel 2) dapat diketahui bahwa lulur serbuk kulit buah manggis dan serbuk kopi menunjukkan lulur homogen karena bahan dan basis terdispersi sempurna.

C. Hasil Uji pH

Hasil uji $\mathrm{pH}$ dapat dilihat pada tabel 2. $\mathrm{pH}$ adalah pengatur derajat keasaman suatu sediaan sehingga manjamin sediaan lulur dapat memberikan kenyamanan pada kulit sewaktu digunakan, karena jika pH lulur terlalu basa akan menyebebkan kulit bersisik dan jika $\mathrm{pH}$ terlalu asam akan menyebabkan iritasi kulit. Hasil uji $\mathrm{pH}$ menunjukkan bahwa dari ketiga formula lulur serbuk kulit buah manggis dan serbuk kopi mempunyai hasil yang sama yaitu 5, sedangkan lulur x memiliki pH 6 . Hal ini menunjukkan bahwa $\mathrm{pH}$ dari sediaan lulur dapat memberikan kenyamanan dikulit sewaktu digunakan.

D. Hasil Uji Viskositas

Uji viskositas bertujuan untuk mengetahui konsistensi kekentalan suatu sediaan, hasil uji viskositas lulur serbuk kulit buah manggis dan serbuk kopi Berdasarkan tabel 2 dapat disimpulkan bahwa ketiga formula memiliki viskositas yang sangat besar, sesuai dengan standar viskositas menurut Gozali, Abdassah dan Lathiefah (2009) yaitu standar viskositas krim yang ideal yaitu tidak kurang dari $5000 \mathrm{mPa} . \mathrm{s}$, dikarenakan lulur yang dibuat oleh peneliti menggunakan serbuk kulit buah manggis dan serbuk kopi bukan ekstrak kulit buah manggis dan ekstrak kopi, sehingga kekentalan yang dihasilkan sangat besar. 
Tabel 3. Hasil Uji Daya Sebar $\left(\mathrm{cm}^{2}\right)$

\begin{tabular}{lllll}
\hline Beban & F1 & F2 & F3 & Fx \\
\hline U & & & & \\
\hline Beban kaca & 6,85 & 3,916 & 3,81 & 6,173 \\
${ }^{\mathrm{i}}$ Beban kaca + & 8,402 & 5,833 & 4,006 & 8,425 \\
$\mathbf{5 0}$ g & & & \\
\hline $\begin{array}{l}\text { Beban kaca }+ \\
\text { Denan }\end{array}$ & 10,321 & 6,725 & 5,14 & 8,822
\end{tabular}

$100 \mathrm{~g}$

daya sebar digunakan untuk mengetahui $\mathrm{x}$ dimana lulur $\mathrm{x}$ sebagai kontrol seberapa luas lulur dapat meyebar saat ditimpa dengan beban. Hasil uji daya sebar tersaji dalam tabel 3.Berdasarkan hasil pengujian daya sebar menunjukan bahwa formula 1 memiliki daya sebar lebih besar dari pada formula 2 dan formula 3. Lulur x memiliki daya sebar yang besar, formula 1 setara dengan lulur pembanding, Sehingga memenuhi kriteria lulur. Sediaan yang baik yaitu memiliki daya sebar yang luas, karena semakin luas daya sebarnya berarti semakin luas kontak antara obat dengan kulit sehingga absorbsi obatnya pun akan lebih cepat dan memberikan kenyamanan penggunaan sediaan tersebut oleh konsumen.

F. Hasil Uji Daya Lekat

Tabel. 4. Hasil Uji Daya Lekat

\begin{tabular}{ll}
\hline Formula & Wakti \\
\hline F1 & 4 detik \\
\hline F2 & 34 detik \\
\hline F3 & 2 menit 44 detik \\
\hline Lx & 2 detik
\end{tabular}

Daya lekat merupakan kemampuan dari sediaan untuk melekat pada kulit dalam jangka waktu lama saat dipakai. Semakin 
lama daya lekat suatu sediaan, maka semakin lama waktu penetrasi obat ke kulit sehingga absorbsi obat akan lebih maksimal. Tujuan uji daya lekat yaitu untuk mengetahui waktu yang dibutuhkan oleh lulur untuk melekat di kulit. Uji daya lekat dapat dilihat pada tabel Berdasarkan data di atas dapat disimpulkan bahwa formula 3 memiliki waktu daya lekat yang lebih lama dibandingkan formula 1 , formula 2 dan formula lulur $\mathrm{x}$. Berdasarkan pengamatan uji daya lekat pada formula 1 lebih cepat daya lekatnya hal ini dikarenakan pada saat pembuatan basis lulur tidak terlalu kental sehingga mempengaruhi daya lekat dan daya lekatnya pun menjadi lebih besar.

\section{KESIMPULAN}

Hasil penelitian yang telah dilakukan menunjukkan bahwa sediaan lulur yang terbaik adalah formula 1 yang menggunakan perbandingan serbuk rimpang kunyit memiliki lulur warna coklat muda, lulur homogen dan menyatu sempurna, memiliki pH 5, daya sebar 10,321 cm2, memiliki konsistensi viskositas $99.000 \mathrm{mPa} . \mathrm{s}$ dan daya lekat selama 4 detik.

\section{DAFTAR PUSTAKA}

Anonim, 2006. Indeks TumbuhTumbuhan Obat Indonesia, Edisi Ke2, PT. Eisai Indonesia, hlm.271

Desyntia, D. 2012. Sehat Dengan Secangkir Kopi. Surabaya: Stomata Fauzi, Aceng Ridwan dan Nurmalina, Rina. 2012. Merawat Kulitdan Wajah. Jakarta: PT. Elex Media Komputindo. Heriana, Arief. 2013. 262 TumbuhanObat

Dan Khasiatnya.PenebarSwadaya: Jakarta.

Tranggono, Retno Iswari dan Latifah, F. 2007. Buku Pegangan Ilmu Pengetahuan Kosmetik. Gramedia Pustaka Utama, Jakarta.

Gozali, D., Abdassah, M., dan Lathiefah, S., 2009, Formulasi Krim Pelembab Wajah yang Mengandung Tabir Surya Nano Partikel Zink Oksida Salut Silikon, Jurnal Farmaka. 